\title{
Survey of 3765 cardiopulmonary resuscitations in British hospitals (the BRESUS study): methods and overall results
}

\author{
Hugh Tunstall-Pedoe, L Bailey, D A Chamberlain, A K Marsden, M E Ward, D A Zideman
}

Abstract
Objective-To determine the circumstances, incidence, and outcome of cardiopulmonary resuscitation in British hospitals.

Design-Hospitals registered all cardiopulmonary resuscitation attempts for 12 months or longer and followed survival to one year.

Setting-12 metropolitan, provincial, teaching, and non-teaching hospitals across Britain.

Subjects -3765 patients in whom a resuscitation attempt was performed, including 927 in whom the onset of arrest was outside the hospital.

Main outcome measure-Survival after initial resuscitation, at 24 hours, at discharge from hospital, and at one year, calculated by the life table method.

Results - There were 417 known survivors at one year, with 214 lost to follow up. By life table analysis for every eight attempted resuscitations there were three immediate survivors, two at 24 hours, 1.5 leaving hospital alive, and one alive at one year. Survival at one year was $12.5 \%$ including out of hospital cases and $15.0 \%$ not including these cases. Each hospital year averaged 30 survivors at one year: three who had an arrest outside hospital, seven who had one in the accident and emergency department, seven in the cardiac care unit, 10 in the general wards, and three in other, non-ward areas. Within the hospitals survival rates were best in those who had an arrest in the accident and emergency department, the cardiac care unit, or other specialised units. Outcome varied 12 -fold in subgroups defined by age, type of arrest, and place of arrest.

Conclusion $-71 \%$ of the mortality at one year in patients undergoing attempted resuscitation occurred during the initial arrest. Hospital resuscitation is life saving and cost effective and warrants appropriate attention, training, coordination, and equipment.

\section{Introduction}

The United Kingdom Resuscitation Council was established in 1982 to foster improved knowledge and practice of cardiopulmonary resuscitation. At this time the subject was comparatively neglected in Britain compared with the United States. ${ }^{12}$ As part of a wider programme $^{3-5}$ the council organised a multicentre study of the circumstances, incidence, and outcome of cardiopulmonary resuscitation in hospital aimed at determining what is happening in a part of hospital practice not covered by routine statistics; developing a standard method of recording arrests that could be used for audit, clinical trials, and, possibly, community studies; and providing a British baseline against which results from other countries, changing management, and future surveys could be assessed. ${ }^{6}$ This first paper describes the methods and overall results, with survival followed to one year. Detailed analysis of subgroups will be reported elsewhere.

\section{Methods}

ORGANISATION

The 12 hospitals registered arrests for a year or more. Follow up was for one year. Each hospital's coordinator initiated a logging system, supplementing hospital switchboard records with active monitoring of hospital areas not using emergency calls.

The target was to record all cases of attempted cardiopulmonary resuscitation started in hospital or continued on arrival with the subsequent exclusion of false alarms or recurrences within 24 hours. A designated member of the resuscitation team was responsible for completing the primary record form during the arrest and recorded information up to the dispersal of the team. The hospital coordinator completed a secondary record, with follow up to discharge or six weeks, and forwarded log, primary, and secondary records to Brighton. A tertiary record form took follow up to one year through the general practitioner.

\section{CONTENT}

The primary form recorded the circumstances of the arrest, evidence for the kind of arrest, interventions, composition of the team, outcome of the resuscitation attempt, and judgments on the appropriateness of the attempt and problems encountered. The secondary record concerned the patient's condition at 24 hours and at discharge (or six weeks) with any revised diagnosis. The tertiary record showed survival and condition at one year.

\section{SURVIVAL}

Survival was calculated by the life table method to allow for losses to follow up and is presented as percentage survival through four single and two composite time periods. The single periods were: (1) through the arrest; (2) from the arrest to 24 hours; (3) from 24 hours to discharge or six weeks; and (4) from discharge or six weeks to one year. The probability of survival through more than one period is the multiple of the individual probabilities. The two chosen combinations were: $2-4$ (that is, $2 \times 3 \times 4$ )-survival to one year after successful resuscitation-and 1-4 (that is, $1 \times 2 \times 3 \times 4)$-survival to one year from the onset of the arrest.

As this is a descriptive study with multiple comparisons formal statistical tests were kept to a minimum. Numbers were great enough in the larger groups to show highly significant differences in survival.

\section{Results}

NUMBERS OF HOSPITALS AND EVENTS

Hospitals were recruited serially after pilot testing. The returns of the hospital recruited first ran from January 1985 and those of that recruited last from November 1985. Eight hospitals (table I) exceeded the one year minimum follow up, so the study covers 15.5 hospital years and 3765 arrests. These averaged 243 a hospital year, or just over 20 in each hospital each month (range 12-33). The number correlates better with an index of turnover-admissions to the cardiac care unit - than with the reported number of acute beds (which may not be consistently defined).

A total of 417 survivors of the 3765 resuscitation 
attempts were identified at one year. In all, 214 were lost to follow up: 110 were not traced beyond the resuscitation; outcome was not known after 24 hours in 20 ; and of 623 alive at discharge, 84 were not traced.

By using life table analysis, to allow for missing data, survival through the resuscitation was $38.7 \%$. In all, $71.7 \%$ of these initial survivors lived to 24 hours; of these, $62 \cdot 7 \%$ lived to hospital discharge or six weeks, and $71 \cdot 8 \%$ of these patients lived to one year. The proportion of initial survivors who lived to one year was therefore $32 \cdot 4 \%$, and survival through resuscitation to one year was $12 \cdot 5 \%$

Table II shows results by sex and age. Survival was similar in men and women at each follow up when all

TABLE I-Participating hospitals, length of participation, and numbers of acute beds, cardiac care unit admissions, and resuscitation attempts during studv

\begin{tabular}{lcccc}
\hline Hospital & $\begin{array}{c}\text { No of } \\
\text { months } \\
\text { in study }\end{array}$ & $\begin{array}{c}\text { No of } \\
\text { acue } \\
\text { beds }\end{array}$ & $\begin{array}{c}\text { No of } \\
\text { cardiac care unit } \\
\text { admissions }\end{array}$ & $\begin{array}{c}\text { No of } \\
\text { resuscitation } \\
\text { attempts }\end{array}$ \\
\hline Royal Sussex County & 26 & 378 & 1537 & 702 \\
Hammersmith, London & 17 & 632 & 413 & 211 \\
Ninewells, Dundee & 22 & 784 & 951 & 297 \\
Leicester Royal Infirmary & 14 & 850 & 966 & 297 \\
Edgware General, London & 13 & 348 & 806 & 244 \\
Frenchay, Bristol & 12 & 568 & 300 & 194 \\
Northampton General & 12 & 551 & 917 & 205 \\
Royal Victoria Infirmary, Newcastle & 14 & 583 & 525 & 248 \\
Royal Free, London & 18 & 720 & 750 & 457 \\
Stockport and Stepping Hill & 12 & 750 & 1224 & 215 \\
Edinburgh Royal Infirmary & 12 & 800 & 1400 & 394 \\
Southend & 14 & 630 & 642 & 301 \\
\hline Total & 186 & 7705 & 10431 & 3765 \\
\hline
\end{tabular}

ages are combined and generally similar in each age group, but men who had an arrest outnumbered women who had one by almost two to one, except beyond the age of 85 . Lower survival rates in elderly people resulted from a lower initial success rate and also a higher attrition rate thereafter, which was greater before discharge than after. The initial success rate was near $30 \%$ in people above 75 years, but survival at one year was below $10 \%$; in contrast $20 \%$ of people aged 25-44 survived to one year.

\section{PLACE OF ARREST}

Table III gives results by place of onset of the arrest. Patients in whom resuscitation was initiated outside hospital and continued on arrival had only $40 \%$ of the study average survival at one year. Their initial survival was half the study average, and there was also greater attrition after 24 hours. Patients who had an arrest in the accident and emergency department were similar in terms of number and survival to those who had one in the cardiac care unit, and, like those who had one in specialised non-ward areas, had an initial survival rate near $50 \%$ and a one year survival near $20 \%$. However, half of the arrests in hospital occurred in patients on general wards, and survival was lower at each stage, during the arrest and subsequently, yielding a one year survival of $11 \%$. Analysis of cases occurring in hospital alone by sex and age group shows a pattern similar to that in table II but with improved survivaldramatically so in children, where out of hospital cases accounted for most deaths and there were no survivors.

TABLE II - Numbers of cases, losses to follow up, and survivors at one year and percentage survival through each stage, by sex and age group

\begin{tabular}{|c|c|c|c|c|c|c|c|c|c|}
\hline \multirow[b]{2}{*}{$\begin{array}{c}\text { Age } \\
\text { group } \\
\text { (years) }\end{array}$} & \multirow[b]{2}{*}{$\begin{array}{l}\text { No } \\
\text { of } \\
\text { cases }\end{array}$} & \multirow[b]{2}{*}{$\begin{array}{c}\text { No } \\
\text { lost to } \\
\text { follow up }\end{array}$} & \multirow[b]{2}{*}{$\begin{array}{l}\text { No } \\
\text { alive at } \\
\text { l year }\end{array}$} & \multicolumn{6}{|c|}{ Percentage survival } \\
\hline & & & & $\begin{array}{c}\text { Through } \\
\text { arrest }\end{array}$ & $\begin{array}{l}\text { From } \\
\text { arrest to } \\
24 \mathrm{~h}\end{array}$ & $\begin{array}{c}\text { From } \\
24 \text { h to } \\
\text { discharge }\end{array}$ & $\begin{array}{c}\text { From } \\
\text { discharge to } \\
1 \text { year }\end{array}$ & $\begin{array}{l}\text { From } \\
\text { arrest to } \\
1 \text { year }\end{array}$ & $\begin{array}{l}\text { Through } \\
\text { arrest } \\
\text { to } 1 \text { year }\end{array}$ \\
\hline \multicolumn{10}{|c|}{ Men } \\
\hline $0-14$ & 48 & 2 & 8 & 27 & 88 & 91 & 84 & 67 & 18 \\
\hline-24 & 37 & 2 & 4 & 27 & 63 & 83 & 89 & 47 & 13 \\
\hline-34 & 48 & 5 & 7 & 38 & 89 & 77 & 70 & 48 & 18 \\
\hline-44 & 91 & 8 & 20 & 47 & 84 & 80 & 78 & 53 & 25 \\
\hline-54 & 240 & 20 & 49 & 47 & 75 & 76 & 88 & 50 & 23 \\
\hline-64 & 571 & 34 & 74 & 42 & 76 & 68 & 66 & 34 & 14 \\
\hline-74 & 745 & 29 & 67 & 39 & 71 & 52 & 68 & 25 & 10 \\
\hline-84 & 428 & 21 & 33 & 36 & 67 & 56 & 63 & 24 & 9 \\
\hline$\geqslant 85$ & 64 & 2 & 3 & 33 & 54 & 48 & 60 & 15 & 5 \\
\hline Not known & 145 & 6 & 6 & 21 & 86 & 42 & 67 & 24 & 5 \\
\hline Total & 2417 & 129 & 271 & $38 \cdot 5$ & $73 \cdot 1$ & $62 \cdot 6$ & $71 \cdot 0$ & $32 \cdot 5$ & $12 \cdot 5$ \\
\hline \multicolumn{10}{|c|}{ Women } \\
\hline $0-14$ & 36 & 3 & 5 & 28 & 74 & 92 & 91 & 62 & 17 \\
\hline-24 & 16 & 4 & 2 & 44 & 77 & 89 & 67 & 46 & 20 \\
\hline-34 & 28 & 2 & 5 & 61 & 85 & 43 & 91 & 33 & 20 \\
\hline-44 & 47 & 4 & 8 & 43 & 68 & 72 & 94 & 46 & 20 \\
\hline-54 & 84 & 6 & 12 & 49 & 76 & 50 & 89 & 34 & 16 \\
\hline-64 & 248 & 23 & 39 & 47 & 79 & 72 & 69 & 39 & 18 \\
\hline-74 & 392 & 22 & 42 & 42 & 65 & 64 & 68 & 29 & 12 \\
\hline-84 & 358 & 14 & 23 & 31 & 61 & 54 & 70 & 23 & 7 \\
\hline$\geqslant 85$ & 77 & 3 & 5 & 26 & 74 & 57 & 67 & 28 & 7 \\
\hline Not known & 62 & 4 & 5 & 31 & 47 & 63 & 100 & 29 & 9 \\
\hline Total & 1348 & 85 & 146 & $39 \cdot 0$ & $69 \cdot 0$ & $62 \cdot 9$ & $73 \cdot 2$ & $31 \cdot 8$ & $12 \cdot 4$ \\
\hline Overall total & 3765 & 214 & 417 & $38 \cdot 7$ & $71 \cdot 7$ & $62 \cdot 7$ & $71 \cdot 8$ & $32 \cdot 4$ & $12 \cdot 5$ \\
\hline
\end{tabular}

\begin{tabular}{|c|c|c|c|c|c|c|c|c|c|}
\hline \multirow[b]{2}{*}{ Place of onset } & \multirow[b]{2}{*}{$\begin{array}{l}\text { No } \\
\text { of } \\
\text { cases }\end{array}$} & \multirow[b]{2}{*}{$\begin{array}{c}\text { No } \\
\text { lost to } \\
\text { follow up }\end{array}$} & \multirow[b]{2}{*}{$\begin{array}{l}\text { No } \\
\text { alive at } \\
\text { l year }\end{array}$} & \multicolumn{6}{|c|}{ Percentage survival } \\
\hline & & & & $\begin{array}{c}\text { Through } \\
\text { arrest }\end{array}$ & $\begin{array}{l}\text { From } \\
\text { arrest to } \\
24 \mathrm{~h}\end{array}$ & $\begin{array}{c}\text { From } \\
24 \text { h to } \\
\text { discharge }\end{array}$ & $\begin{array}{c}\text { From } \\
\text { discharge to } \\
1 \text { year }\end{array}$ & $\begin{array}{c}\text { From } \\
\text { arrest to } \\
\text { to } 1 \text { year }\end{array}$ & $\begin{array}{l}\text { Through } \\
\text { arrest } \\
\text { to } 1 \text { year }\end{array}$ \\
\hline Outside hospital ( 915 cases) or unspecified ( 12 cases) & 927 & 24 & 41 & 20 & 74 & 53 & 64 & 25 & 5 \\
\hline Inside hospital (all locations) & 2838 & 190 & 376 & 45 & 71 & 64 & 73 & 33 & 15 \\
\hline Accident and emergency department & 580 & 44 & 97 & 49 & 72 & 68 & 79 & 39 & 19 \\
\hline Cardiac care unit & 612 & 34 & 108 & 49 & $7 \overline{4}$ & 70 & 77 & 40 & 19 \\
\hline Intensive care unit, theatres, investigation rooms & 143 & 14 & 21 & 52 & 76 & 56 & 78 & 33 & 17 \\
\hline Other hospital (non-ward) areas & 116 & 11 & 21 & 50 & 73 & 78 & 72 & 41 & 21 \\
\hline General wards & 1387 & 87 & 129 & 40 & 69 & 58 & 65 & 26 & 11 \\
\hline
\end{tabular}




\begin{tabular}{|c|c|c|c|c|c|c|c|c|c|}
\hline \multirow[b]{2}{*}{ Type of arrest } & \multirow[b]{2}{*}{$\begin{array}{l}\text { No } \\
\text { of } \\
\text { cases }\end{array}$} & \multirow[b]{2}{*}{$\begin{array}{c}\text { No } \\
\text { lost to } \\
\text { follow up }\end{array}$} & \multirow[b]{2}{*}{$\begin{array}{l}\text { No } \\
\text { alive at } \\
\text { l year }\end{array}$} & \multicolumn{6}{|c|}{ Percentage survival } \\
\hline & & & & $\begin{array}{c}\text { Through } \\
\text { arrest }\end{array}$ & $\begin{array}{l}\text { From } \\
\text { arrest to } \\
24 \mathrm{~h}\end{array}$ & $\begin{array}{c}\text { From } \\
24 \text { h to } \\
\text { discharge }\end{array}$ & $\begin{array}{c}\text { From } \\
\text { discharge to } \\
1 \text { year }\end{array}$ & $\begin{array}{l}\text { From } \\
\text { arrest to } \\
\text { to } 1 \text { year }\end{array}$ & $\begin{array}{l}\text { Through } \\
\text { arrest } \\
\text { to } 1 \text { year }\end{array}$ \\
\hline Cardiac & 2103 & 126 & 272 & 41 & 75 & 65 & 72 & 35 & 14 \\
\hline Respiratory & 421 & 46 & 65 & 60 & 69 & 61 & 73 & 31 & 18 \\
\hline Both cardiac and respiratory & 694 & 24 & 42 & 27 & 66 & 53 & 72 & 25 & 7 \\
\hline Other & 99 & 7 & 14 & 52 & 67 & 65 & 72 & 31 & 16 \\
\hline No information & 54 & 3 & 4 & 44 & 60 & 44 & 73 & 19 & 9 \\
\hline Not known & 394 & 8 & 20 & 18 & 68 & 62 & 71 & 30 & 5 \\
\hline
\end{tabular}

TABLE V-Survival by place of onset of arrest, type of arrest, and age

\begin{tabular}{|c|c|c|c|c|c|c|c|c|c|}
\hline & \multirow[b]{2}{*}{$\begin{array}{l}\text { No } \\
\text { of } \\
\text { cases }\end{array}$} & \multirow[b]{2}{*}{$\begin{array}{c}\text { No } \\
\text { lost to } \\
\text { follow up }\end{array}$} & \multirow[b]{2}{*}{$\begin{array}{l}\text { No } \\
\text { alive at } \\
1 \text { year }\end{array}$} & \multicolumn{6}{|c|}{ Percentage survival } \\
\hline & & & & $\begin{array}{l}\text { Through } \\
\text { arrest }\end{array}$ & $\begin{array}{l}\text { From } \\
\text { arrest to } \\
24 \mathrm{~h}\end{array}$ & $\begin{array}{c}\text { From } \\
24 \mathrm{~h} \text { to } \\
\text { discharge }\end{array}$ & $\begin{array}{c}\text { From } \\
\text { discharge to } \\
1 \text { year }\end{array}$ & $\begin{array}{l}\text { From } \\
\text { arrest to } \\
\text { to } 1 \text { year }\end{array}$ & $\begin{array}{l}\text { Through } \\
\text { arrest } \\
\text { to } 1 \text { year }\end{array}$ \\
\hline \multicolumn{10}{|c|}{ Out of hospital, cardiac arrest: } \\
\hline$<65$ & 194 & 8 & 15 & 26 & 84 & 62 & 65 & 34 & 9 \\
\hline$\geqslant 65$ & 259 & 3 & 12 & 24 & 70 & 49 & 57 & 20 & 5 \\
\hline \multicolumn{10}{|c|}{ Out of hospital, arrests other than cardiac: } \\
\hline$<65$ & 237 & 7 & 9 & 16 & 68 & 57 & 72 & 28 & 5 \\
\hline$\geqslant 65$ & 237 & 6 & 5 & 15 & 70 & 36 & 67 & 17 & 2 \\
\hline \multicolumn{10}{|c|}{ General wards, cardiac arrest: } \\
\hline$<65$ & 192 & 19 & 26 & 47 & 73 & 66 & 69 & 33 & 16 \\
\hline$\geqslant 65$ & 516 & 24 & 35 & 35 & 69 & 55 & 56 & 21 & 8 \\
\hline \multicolumn{10}{|c|}{ General wards, arrests other than cardiac: } \\
\hline$<65$ & 259 & 19 & 35 & 53 & 68 & 57 & 76 & 30 & 16 \\
\hline$\geqslant 65$ & 420 & 25 & 33 & 36 & 66 & 59 & 63 & 25 & 9 \\
\hline \multicolumn{10}{|c|}{ Specialised hospital areas, cardiac arrest: } \\
\hline$<65$ & 395 & 44 & 106 & 57 & 85 & 81 & 78 & 54 & 31 \\
\hline$\geqslant 65$ & 547 & 28 & 78 & 48 & 70 & 60 & 77 & 33 & 16 \\
\hline \multicolumn{10}{|c|}{ Specialised hospital areas, arrests other than cardiac: } \\
\hline$<65$ & 217 & 16 & 42 & 49 & 76 & 76 & 76 & 44 & 22 \\
\hline$\geqslant 65$ & 292 & 15 & 21 & 40 & 57 & 47 & 75 & 20 & 8 \\
\hline
\end{tabular}

TABLE VI-Survival by number of defibrillations

\begin{tabular}{|c|c|c|c|c|c|c|c|c|c|}
\hline \multirow[b]{2}{*}{$\begin{array}{c}\text { No } \\
\text { of } \\
\text { shocks }\end{array}$} & \multirow[b]{2}{*}{$\begin{array}{l}\text { No } \\
\text { of } \\
\text { cases }\end{array}$} & \multirow[b]{2}{*}{$\begin{array}{c}\text { No } \\
\text { lost to } \\
\text { follow up }\end{array}$} & \multirow[b]{2}{*}{$\begin{array}{c}\text { No } \\
\text { alive at } \\
1 \text { year }\end{array}$} & \multicolumn{6}{|c|}{ Percentage of survival } \\
\hline & & & & $\begin{array}{c}\text { Through } \\
\text { arrest }\end{array}$ & $\begin{array}{l}\text { From } \\
\text { arrest to } \\
24 \mathrm{~h}\end{array}$ & $\begin{array}{c}\text { From } \\
24 \mathrm{~h} \text { to } \\
\text { discharge }\end{array}$ & $\begin{array}{c}\text { From } \\
\text { discharge to } \\
1 \text { year }\end{array}$ & $\begin{array}{l}\text { From } \\
\text { arrest to } \\
\text { to } 1 \text { year }\end{array}$ & $\begin{array}{c}\text { Through } \\
\text { arrest } \\
\text { to } 1 \text { year }\end{array}$ \\
\hline 0 & 1987 & 112 & 169 & 38 & 64 & 59 & 68 & 26 & 10 \\
\hline 1 & 566 & 45 & 124 & 54 & 79 & 71 & 79 & 45 & 24 \\
\hline 2 & 393 & 20 & 51 & 42 & 79 & 66 & 65 & 34 & 14 \\
\hline 3 & 277 & 9 & 35 & 34 & 82 & 62 & 78 & 40 & 14 \\
\hline 4 & 194 & 12 & 11 & 29 & 75 & 47 & 69 & 24 & 8 \\
\hline 5 & 76 & 5 & 9 & 28 & 87 & 77 & 75 & 50 & 14 \\
\hline 6 & 89 & 4 & 4 & 18 & 64 & 89 & 62 & 35 & 6 \\
\hline $7-9$ & 80 & 1 & 4 & 23 & 86 & 33 & 80 & 23 & 5 \\
\hline$\geqslant 10$ & 51 & 3 & 3 & 25 & 88 & 50 & 60 & 26 & 7 \\
\hline Not known & 52 & 3 & 7 & 37 & $\begin{array}{l}00 \\
76\end{array}$ & 64 & 88 & $\begin{array}{l}20 \\
43\end{array}$ & 16 \\
\hline
\end{tabular}

MODE OF ARREST

The initial record form asked if the arrest fell into the categories of primarily cardiac, primarily respiratory, both, other, or not known. Table IV shows that $56 \%$ of arrests were classified as primarily cardiac, $11 \%$ as respiratory, and $18 \%$ as both, with the remainder indeterminate. People who had arrests categorised as both cardiac and respiratory had a poor initial and subsequent survival rate. Those who had a cardiac arrest and those who had a respiratory arrest had a similar one year survival; those with cardiac arrests had a poorer initial survival but a safer subsequent hospital course. Prognosis from discharge to one year was the same for both types of arrest.

\section{RISK GROUPS}

Table $\mathrm{V}$ gives results for three places of onset (outside hospital, general hospital wards, and other hospital areas from table III), two modes of arrest (primarily cardiac and all other categories, including unknown), and two age groups (below 65 and 65 and above).

People below age 65 who had a cardiac arrest in specialised hospital areas-predominantly accident and emergency departments and cardiac care unitshad an initial success rate of $57 \%$ and a one year survival rate of $31 \%$, much better than the study average. These accounted for only $14 \%$ of arrests occurring in hospital and $10 \%$ of all arrests and comprise the one good risk category, whereas seven groups had a one year survival below $10 \%$. The three simple descriptors together give a four to one gradient in survival at one year for arrests in hospital, and a 12 to one gradient overall $\left(\chi^{2}=166, \mathrm{df}=11, \mathrm{p}<0.0001\right)$, and each operates across subgroups, except that those having cardiac arrests fared as badly as those having other arrests on the general hospital wards.

\section{MEDICAL CARE}

The incidence and outcome of arrests did not vary appreciably by day of the week. Outcome in patients whose arrest was witnessed was better than in those found in the arrest (immediate survival $48 \% v$ $32 \%)$. Classification as to whether arrests were unexpected, considered likely, or complications of surgical or medical procedures showed little difference in outcome.

Survival decreased with increasing numbers of defibrillations from one (table VI), but much of this difference in one year mortality occurred during the arrest. There was some decline in survival after arrest in people who received more than six shocks, but the overall gradient is not steep.

Analysis of size of the arrest team showed a modal 
value of six members, but there were eight or more present during one third of arrests. The best outcomes were in the small proportion of arrests managed by two or three people. Survival in each of the three hospital time periods decreased with increasing numbers involved in the resuscitation attempt, even though they were present only in the first period, but there was no difference after discharge.

\section{Discussion}

\section{UNDER AND OVERREPORTING OF EVENTS}

Some resuscitation attempts were probably missed, unlogged, and unreported, or logged without a matching form. Hospital coordinators found on inquiry that most of those logged without a form were false alarms, but some simply could not be traced. On the other hand, arrest calls were made for collapsed patients whose disease was varied. A search of 263 forms which recorded no defibrillation, no cardiac compression, and no pacing showed that almost all were genuine arrests-respiratory arrests where ventilation, intubation, or other interventions restored respiration, or cardiac arrests that reverted spontaneously or after a precordial thump-or narrative showed that the coding was wrong. Probably more genuine arrests were missed than false ones included but these were impossible to quantify.

\section{REPRESENTATIVES OF THE RESULTS}

The average hospital had 30 one year survivors each year: three had had an arrest outside hospital; seven had one in the accident and emergency department; seven in the cardiac care unit; 10 in the general wards; 1.5 in intensive care, theatres, or investigation rooms; and 1.5 in other hospital, non-ward areas. For each one year survivor there were eight attempted resuscitations, three initial survivors, about two surviving the first 24 hours, and 1.5 leaving hospital alive.

These results should be typical of British hospitals but this is arguable both because the participating hospitals varied and because they were not chosen at random. Participation involved commitment and coordination which some potential recruits found they could not deliver. None the less our list included metropolitan, provincial, and teaching and nonteaching hospitals.

Comparison of results between hospitals and case series is jeopardised by different selective biases: age and case mix, the choice of whether some or all patients are subjected to attempted resuscitation, and criteria for deciding which cases are included. This report concerns all cases of suspected cardiac or respiratory arrest, including those whose documentation was incomplete, to give a comprehensive picture. Later reports will feature subgroups defined more restrictively for specific analyses.

The difficulties of comparing results in resuscitation studies, particularly for resuscitation attempts made outside of hospital, have led to a recent call for uniform criteria for recording and reporting data. ${ }^{7}$ These criteria cannot be applied retrospectively to published work on resuscitation in hospital, which comes predominantly from teaching hospitals, ${ }^{8.13}$ with a few studies in nonteaching hospitals, ${ }^{14-16}$ studies in accident and emergency departments, ${ }^{17-19}$ a review of the first 25 years, ${ }^{20}$ and another large national survey from Belgium, albeit with a main emphasis on out of hospital resuscitation. ${ }^{2}$

Survival in our study is in line with these reports. The Belgian study reported an initial success rate of $34 \%$ and a success rate of $18 \%$ at two weeks. ${ }^{21} \mathrm{McGrath}$ reviewed 12961 patients in 42 papers and reported an average survival rate of $38.5 \%$ at 24 hours (range 13 $59 \%$ ) and $14.6 \%$ at discharge (range $3-27 \%$ ), ${ }^{20}$ while DeBard's earlier review quotes figures of $39 \%$ and at discharge home of $17 \% .^{9}$ Our figures show an immediate survival of $39 \%$, a survival of $28 \%$ at 24 hours, $17 \%$ at discharge home, and $12.5 \%$ at one year; if arrests that occurred out of hospital are excluded the results are $45 \%, 32 \%, 21 \%$, and $15 \%$ respectively.

\section{RISK FACTORS}

Age (table II) and the place of arrest (table III) affected survival. Earlier studies implied that age does not affect survival after arrest, ${ }^{8}$ and that location does not influence immediate outcome, ${ }^{912}$ but the larger numbers in our study show these effects to be both immediate and delayed, as well as confirming good results from onset of arrest in accident and emergency departments. ${ }^{97} 179$ The results suggest that combined cardiac and respiratory arrest is more deadly than either alone. As these do not occur simultaneously this may be more an indication of time before help arrived than of primary disease. In combination (table V) the three variables-age, place of arrest, and type of arrest-define subgroups with major differences in survival rates, but none in which rates are so bad as to preclude resuscitation, unlike in other studies which report no survivors over age $70,{ }^{16}$ or among out of hospital cases brought into hospital. ${ }^{22}$

Resuscitation may reverse the arrest and its acute precipitants, but advanced age and underlying chronic disease may lead to a poor prognosis, especially in general hospital wards. ${ }^{1314}$ However, if after one year seven lives out of eight are lost, these figures show that five of the seven people die during the index arrest. The greatest potential for improving long term survival may be in increasing the initial survival rates.

The estimates of time delays in resuscitation reported to us have not been analysed here, but our results suggest that speed and competence of response and duration of episode contribute to initial survival. Patients whose arrests are witnessed, are known to be primarily cardiac or respiratory, and occur in high surveillance areas have the best prognosis. Declining survival with the size of the resuscitation team and the number of defibrillations suggest that prolonged resuscitation has a poorer outcome. It takes time for a resuscitation team of more than six to congregate - this is more likely to be necessary in difficult cases. The number of defibrillations is related to duration of the arrest but also to the persistence or recurrence of ventricular fibrillation as distinct from ventricular asystole. Table VI suggests that the initial survivors of multiple shocks do as well or better than those who have none at all. Analyses of specific rhythms will be reported elsewhere.

\section{IMPLICATIONS FOR RESUSCITATION MANAGEMENT}

Since this study was initiated in the mid-1980s there have been developments which promise better results in the future. Widespread deployment of ambulances with trained staff and defibrillators is changing the potential for resuscitation out of hospital. ${ }^{23}$ Increasing awareness of remediable deficiencies in the training of hospital staff ${ }^{4-27}$ led the Resuscitation Council to promote British (and potentially European) guidelines for standardising resuscitation procedures and hospital training. ${ }^{3-5}$ Following the recommendations of the Royal College of Physicians, hospitals are setting up resuscitation committees, appointing resuscitation training officers, and auditing their results by using simplified record forms derived from this study. ${ }^{28}$ Compared with other life saving interventions hospital resuscitation is seen to be cost effective and a procedure where improved speed of reaction, training, and competence should produce improved results.

The Resuscitation Council research working group is indebted to the hospital staff who completed the record forms 
and the hospital coordinators from candidate and chosen hospitals for their efforts. Coordinators were: Dr S Bowler, Mr C Brown, Dr M Clark, Ms G Colbourne, Dr S Davies, Mrs A Elling, Dr C Gordon, Ms K Hufton, Dr G Main, Dr J V Mannakkara, Dr R D Marshall, Mr G R Millar, $\mathrm{Mr} \mathrm{T}$ Payne, Miss J Porter, Mr A D Redmond, Dr C Robertson, Miss G Wynne. Coordination and data processing for the project in Sussex University were financed by two consecutive grants from the Laerdal Foundation, one from the British Heart Foundation, and supplements from several hospital and medical school sources. Final analysis was carried out in Dundee with the programming assistance of $\mathrm{Mr}$ Colin Brown. We also thank Professor A J Camm, who joined the research working group after this study had been mounted.

1 American Heart Association. Standards and guidelines for cardiopulmonary resuscitation (CPR) and emergency cardiac care (ECC). FAMA 1980:244 453-509.

2 Kaye W, Linhares KC, Breault RC, Norris PA, Stamoulis CC, Khan AH. The mega-code for training the advanced cardiac life support teams. Heart and Lung 1981;10:860-5.

3 Marsden AK. Basic life support. Revised recommendations of the Resuscitation Council (UK). BMF 1989;299:442-5.

4 Chamberlain DA. Advanced life support. Revised recommendations of the Resuscitation Council (UK). BMf 1989;299:446-8.

5 Evans TR, ed. $A B C$ of resuscitation. 2nd ed. London: British Medical Journal, 1990 fournal of the World Association for Emergency and Disaster Medicin 1985;1:291-2.

7 Cummins RO, Chamberlain DA, Abramson NA, Allen M, Baskett PJ Becker L, et al. Recommended guidelines for uniform reporting of data from out-of-hospital cardiac arrest: the Utstein Style. Circulation 1991;84 960-76. resuscitation in the hospital. $N$ Engl f Med 1983;309:569-76.

9 DeBard ML. Cardiopulmonary resuscitation: analysis of six years experience and review of the literature. Ann Emerg Med 1981;10:408-16.

10 Wildsmith JAW, Dennyson WG, Myers KW. Results of resuscitation following cardiac arrest. A review from a major teaching hospital. Br f Anaesth 1972;44:716-9.

11 Scott RPF. Cardiopulmonary resuscitation in a teaching hospital. Anaesthesia 1981;36:526-30.

\section{Measuring the heights of very young children}

\section{P R Betts, L D Voss, B J R Bailey}

Department of Paediatrics and Child Health, Southampton General Hospital, Southampton P R Betts, consultant paediatrician

Wessex Growth Study, Southampton General Hospital L D Voss, research fellow

Faculty of Mathematical Studies, University of Southampton, Southampton B J R Bailey, lecturer

Correspondence to: $\mathrm{Dr}$ Betts.

BMF 1992;304:1351-2

Pooled SDs of single height measurements (SDshm) by age group

\begin{tabular}{lc}
\hline Age group & SDshm $(\mathrm{cm})$ \\
\hline 19-23 months & 0.55 \\
3 years & 0.23 \\
4-11 years & 0.23 \\
\hline
\end{tabular}
height measuring instruments, ${ }^{\prime}$ finding that the Harpenden stadiometer was no more reliable than the cheaper Raven minimetre. ${ }^{1}$ We examine the reproducibility of height measurement in very young children aged 18 months to 2 years and in children aged 3 years, comparing these results with those reported in older children.

\section{Subjects, methods, and results}

Twenty seven children aged 19-23 months and 25 children aged from 2 years 10 months to 3 years 8 months attended their local community health clinic. Of the 27 youngest children, eight were crying or struggling while being measured, and the variance of their measurements was slightly higher than that of the other children in the group, but not significantly so $(p=0.072)$. Their results were included in the analysis.

A Raven minimetre was used to measure the children. Two experienced auxologists measured each child twice in separated measurements. In addition, the mothers ensured that the children's heels were on the floor. For each measurer and group the SD of a single height measurement was calculated. ${ }^{\prime}$

In the three age groups (19-23 months, 3 years, $4-11$ years) there was no significant difference between the two measurers in the SD of a single height measurement
6 Zideman DA. Cardiopulmonary resuscitation - the need for national surveys.

8 Bedell SE, Delbanco TL, Cook EF, Epstein FH. Surival after cardiopulmonary

12 Suljaga-Pechtel K, Goldberg E, Strickos P, Berger M, Skovron ML. Cardiopulmonary resuscitation in a hospitalized population: prospective study of factors associated with outcome. Resuscitation 1984;12:77-95.

13 George AL, Folk BP, Crecelius PL, Campbell WB. Pre-arrest morbidity and other correlates of survival after in-hospital cardiopulmonary resuscitation. Am ₹ Med 1989;87:28-34.

14 Hershey CO, Fisher L. Why outcome of cardiopulmonary resuscitation in general wards is poor. Lancet 1982;i:31-4.

15 Roser LA. Cardiopulmonary resuscitation experience in a general hospital. Arch Surg 1967;95:658-63.

16 Taffet GE, Teasdale TA, Luchi RJ. In-hospital cardiopulmonary resuscitation 7AMA 1988;260:2069-72.

17 Wardrope J, Crosby AC, Ferguson DG, Edbrooke DL. A computerized prospective audit of cardiopulmonary resuscitation in the accident and emergency department. Arch Emerg Med 1986;3:183-91.

18 Robertson CE, Little K. Cardiopulmonary resuscitation in the accident and emergency department. Arch Emerg Med 1984;1:17-32.

19 Cope AR, Quinton DN, Dove AF, Sloan JP, Dave SH. Survival from cardiac arrest in the accident and emergency department. $f R$ Soc Med 1987;80: 746-9.

20 McGrath RB. In-house cardiopulmonary resuscitation-after a quarter of a century. Ann Emerg Med 1987;16:1365-8.

21 Delooz $\mathrm{H}$, ed. Proceedings of a workshop on cardio-pulmonary-cerebral resuscitation of the cerebral resuscitation study group of the Belgian Society for Intensive Care, Beerse, Belgium, 19 Sept 1988. Resuscitation 1989;17:S1-206.

22 Gray WA, Capone RJ, Most AS. Unsuccessful emergency medical resuscitation -are continued efforts in the emergency medical department justified? - are continued efforts in the

23 Cobbe SM, Redmond MJ, Watson JM, Hollingworth J, Carrington DJ. Heartstart Scotland-initial experience of a national scheme for out of hospital defibrillation. $B M \mathcal{F}$ 1991;302:1517-20.

24 Casey WF. Cardiopulmonary resuscitation: a survey of standards among junior hospital doctors. $\mathcal{I} R$ Soc Med 1984;77:921-4.

25 Skinner DV, Camm AJ, Miles S. Cardiopulmonary resuscitation skills of preregistration house officers. BMF 1985;290:1549-50.

26 Wynne G, Marteau TM, Johnston M, Whiteley CA, Evans TR. Inability of trained nurses to perform basic life support. BMF 1987;294:1198-9.

27 Smith GB, Hill SL. Resuscitation training for medical students in the United Kingdom-a comparison with the United States of America. Intensive Care Med 1987;13:260-5.

28 Royal College of Physicians Working Party on Resuscitation. Resuscitation from cardiopulmonary arrest. Training and organisation. $\mathcal{F} R$ Coll Physicians Lond 1987;21:1-8.

(Accepted 10 March 1992)

$(\mathrm{p}=0.15,0.92,0.54$ respectively). Consequently, values were pooled (table). The SD of a single height measurement in children aged $4-11$ years $(0.23 \mathrm{~cm})$ had been obtained by the same two measurers.' The value in the 3 year olds in this study $(0.23 \mathrm{~cm})$ was identical, while that in the youngest group was more than twice as large. Although two observers may measure with similar precision, they may none the less use different measuring techniques that result in different mean heights in the same children. ' Using the minimetre, we found a (highly) significant difference between the mean heights obtained by the two observers for the youngest children $(83.5 \mathrm{~cm}$ and $84.1 \mathrm{~cm}, \mathrm{p}<0.001)$.

\section{Comment}

Height measurement with the Raven minimetre is no less reproducible than with the Harpenden stadiometer, ${ }^{1}$ and the minimetre could, therefore, be used in a community setting by a trained health worker. Struggling children did not significantly increase the error of measurement when a correct technique for measuring was used.

The standard charts available are based on measurements of length up to the age of 2 years and of height thereafter. ${ }^{2}$ In children aged between 18 and 20 months we found that there may be a mean decrease of $2 \mathrm{~cm}$ when changing from the supine (length) to the standing (height) position (unpublished data). We therefore recommend that a child's height, rather than length, be measured once a child can stand.

This study has shown that the SD of a single height measurement obtained by two experienced observers in 3 year old children was comparable with that obtained in older children. That the SD is larger for the youngest children (aged 19-23 months) should not be surprising nor preclude measurement. The spread of height velocity is greater at the age of 2 years than at 